\title{
Nutritional Epidemiological Study to Estimate Usual Intake and to Define Optimum Nutrient Profiling Choice in the Diet of Egyptian Youths
}

\author{
Moushira Zaki' ${ }^{1}$, Laila Hussein ${ }^{2}$, Mostafa Gouda², Rania Bassuoni², Ahmed Hassanein ${ }^{3}$ \\ ${ }^{1}$ Department of Biological Anthropology, National Research Centre, Giza, Egypt \\ ${ }^{2}$ Department of Human Nutrition, National Research Centre, Giza, Egypt \\ ${ }^{3}$ Department Information and Systems, National Research Centre, Giza, Egypt \\ Email: *dr.lailahussein@yahoo.com
}

Received 1 October 2015; accepted 17 November 2015; published 20 November 2015

Copyright (C) 2015 by authors and Scientific Research Publishing Inc.

This work is licensed under the Creative Commons Attribution International License (CC BY). http://creativecommons.org/licenses/by/4.0/

(c) (i) Open Access

\section{Abstract}

Objectives: To define optimum food and nutrient profiling in gender-specific and age group-specific variant regression models. Setting: 481 subjects of both sexes (18.4 years old) from Giza urban were set. Design: Dietary assessment used the 24-h dietary recall data to calculate the estimated energy and (24) nutrients eaten by each individual. Four indices-food variety diversity score, healthy eating index (HEI), mean probability of nutrients adequacy (MPA) and nutrient rich food ( $\mathrm{NRF}_{9.3}$ ) index score were used for assessing the profiling of the diet. Results: $\mathrm{A}$ total of 163 individual food items were consumed by the participants within the 24-h dietary recall with an average daily intake of (6.6) different food varieties. Grains were the top contributors of energy and 10 macro and micro nutrients followed by the meat group. Based on the MPA data, the mean acceptable intake (AI) of dietary calcium $(32.9 \%)$ and vitamin $\mathrm{C}(30 \%)$ were limiting in the diet. The diet profiling consumed by the teenagers aged 14.8 years was inferior compared to that consumed by subjects aging 23.9 years. Linear regression analyses were conducted between the 4 indices as the dependent variable and all possible combinations of 16 nutrients of interest as independent variables. $\mathrm{NRF}_{9.3}$ was the optimum nutrient index and correlated negatively with markers of abdominal obesity. Conclusion: Implementation of nutrition intervention program was directed to youths to include age appropriate good healthy foods to decrease the risk of nutrient deficiencies.

${ }^{*}$ Corresponding author.

How to cite this paper: Zaki, M., Hussein, L., Gouda, M., Bassuoni, R. and Hassanein, A. (2015) Nutritional Epidemiological Study to Estimate Usual Intake and to Define Optimum Nutrient Profiling Choice in the Diet of Egyptian Youths. Food and Nutrition Sciences, 6, 1422-1436. http://dx.doi.org/10.4236/fns.2015.615147 


\section{Keywords}

\section{Egyptian Youths, Healthy Eating Index, Mean Probability Nutrient Adequacy, Nutrient Rich Food Index, Anthropometric Measures of Health Risk, Correlations}

\section{Introduction}

Diet quality indices add an important dimension to dietary assessment and were designed and developed to provide guidelines for the general population especially among youths as a strategy to achieve the healthy people 2020 [1] and to decrease the risk of nutrient deficiencies. The Euro diet food based guidelines selected for nutrient systems had been reported by health authorities in France [2], Germany [3], Holland [4] and Sweden [5]. The American Healthy Eating Index-2010 (HEI-2010) is based on the recommendations of the dietary guidelines advisory committee (DGAC) and has been used as monitoring tool in American populations. The use of the above-mentioned diet indices in epidemiological study predicts the diet-disease associations [1]. There are two types of scores, food based [1] [6] or nutrient based indices [7]-[10].

Nutrient based dietary indices are based on variable nutrients $(n)$ to encourage $(n=6-23)$; while the three to limit (LIM-NRFn.3) were always the same: saturated fat (SFA), added sugar and sodium [1] [5] [7] [8] [11]-[14].

WHO report listed 37 nutrients and other food components linked to chronic disease [10].

Limited accessibility to healthy food choices curtails the consumption of fresh fruits and vegetables and increases the consumption of unhealthy foods. Other contributing factors included the globalization of food supply, increased food advertising especially among adolescents and improvements in the national economies. The consumption of energy-dense, nutrient-poor (EDNP) foods in fast food outlets and snacking poses a barrier against adoption of healthy behavior among teenagers and youths [2]. Two Australian studies demonstrated that extra foods (synonymous name to energy-rich nutrient poor foods; EDNP) made up 35\% of the energy intake among adults [15]. According to the same authors, the extra foods contributed $16 \%$ protein, $41 \%$ total fat, $41 \%$ saturated fat, $47 \%$ sugar; while they provided only $20 \%$ of selected micronutrients to the diet. Such unbalanced diets are modifiable risk factors for the development of obesity, metabolic disorders, causing considerable burden of disease [16].

The health risk increases in a graded fashion when moving from the normal-weight through obese BMI categories (BMI > 97 percentile). In addition, subject with high waist circumference (WC) values (waist circumference $>102 \mathrm{~cm}$ for men and $>88 \mathrm{~cm}$ for women) reflected by abdominal obesity is an independent risk factor for a number of co-morbidities and chronic illnesses, as well as a cluster of metabolic disturbances [17] [18].

Nutrition transition in Egypt over the last few decades resulted in the prevalence of malnutrition and obesity in the country-two pressing public health concerns [19]. The prevalence of obesity is reaching epidemic proportions reaching $16 \%$ and $26 \%$ among male and female adolescents, respectively. Respective figures of $26 \%$ and $40 \%$ were reported among female and male adults [19]. Due to socio-cultural differences, we cannot extrapolate the US and European findings to the Egyptian subjects. The present study aims to define the usual dietary intakes of youths and to define optimum nutrient profiling choice in their diet, which predicts body anthropometric measures of health risk.

\section{Materials and Methods}

\subsection{Subjects}

The study was a cross sectional survey of 481 subjects, who were residents of Giza urban setting. The participants were recruited as part of the prospective youth study project and details of the study population and methodology have been presented elsewhere [20]. Exclusion criteria were ages $<12$ and $>35$ years, history of diabetes, hypertension, heart disease, or endocrine disorders; abnormal blood chemistry profile, fasting triacyl glycerol concentration $>3.39 \mathrm{mmol} / \mathrm{L}(>300 \mathrm{mg} / \mathrm{dL})$, fasting LDL-cholesterol concentration $>3.37 \mathrm{mmol} / \mathrm{L}$ ( $>130 \mathrm{mg} / \mathrm{dL}$ ). Female subjects were neither pregnant nor lactating. The volunteers were instructed to continue to eat their normal diet and not to alter their usual dietary or fluid intake. The subjects visited the national re- 
search centre for clinical examinations; collecting data on lifestyle and risk indicators for chronic diseases and the assessment of their diet. Approval for the study was obtained from the NRC Institutional Review Board, which complied with the revised Helsinki Declaration (2004). The protocol was fully explained to all subjects and written informed consent was obtained from all subjects before their participation in the study.

\subsection{Dietary Assessment}

The 24-hour dietary recall. The subjects were interviewed in person by an experienced dietician; using the multi-pass, 24-h dietary interview method. The respondent was asked to remember all the types and amounts of foods and beverages consumed during the previous 24-h period. Extra emphasis were given to fat type and fat content, added sugars and salt intakes. Due to logistical constraints a repeat dietary recall was not possible. The completed $24 \mathrm{~h}$ dietary recall was reviewed, checked for errors and judged reliable by the interviewer. Unreliability was defined as the inability of the respondent to recall one or more meals or if less than 500 $\mathrm{Kcal} /$ day.

\subsection{Computer-Based Analysis}

The data were processed by data entry using the software NutriSurvey computer-based database. The database has access to append supplemental information on nutrient composition from an in house food file for Egyptian ethnic typical foods data base [21] not represented in the NutriSurvey. The in home data base was used to estimate energy, protein, fat, carbohydrates, dietary fiber intake, saturated fatty acids, retinol equivalent, vitamins B1, B2, B6, B12, niacin, vitamin C, calcium, magnesium, iron, zinc, potassium and sodium. The estimation of total sugars and vitamin E composition were derived from another data base [22]. For each subject, daily intakes (g) of 12 food groups were counted and the amounts were recorded. Dairy products, eggs, fishes, all meats, and poultry, cereals, legumes, vegetables, fruits, juices \& beverages, recipes, sweets and energy-dense, nutrient-poor (EDNP).

\subsection{Anthropometric Measures}

Measurements of body weight and height to calculate body mass index (BMI: Body weight $\mathrm{kg} / \mathrm{stature}, \mathrm{m}^{2}$ ). The cut-off points of $25 \mathrm{~kg} / \mathrm{m}^{2}$ was used to separate the lean from the other categories; i.e., over weight and obese [23]. Waist circumference (WC) and hip circumference (HC) were measured in cm using a plastic, non-stretchable tailor's tape. WC was measured with light clothing at a level midway between the lower rib margin and the iliac crest standing and breathing normally. HC was measured at the level at the widest circumference over the buttocks. The waist hip ratio (W:H ratio) was calculated as WC divided by HC. Waist-to-height ratio was calculated as the ratio of waist circumference over height. Table 1 presents characteristics of the subjects according to age group and BMI.

\subsection{Statistical Analysis}

The generated excel sheet presents each food item consumed by each subject, plus the respective estimated daily intake of the energy, all macro and micro nutrients intakes. Differences in percentages among groups were tested using the non-parametric Chi-square test analyses. The population mean and standard error (SE) of calorie and estimated nutrient intakes from each food group were determined and the observed differences among group means was tested using 1 -way ANOVA at a level of significance $(P$-value $<0.05)$.

\subsection{Estimated Probability of Nutrient Adequacies for Vitamins and Minerals (PNA)}

The age and sex-specific Estimated Average Requirement (EAR) of essential minerals and vitamins [24] was used as reference for expressing the individual daily intake of a nutrient into the respective probability of nutrient adequacy (PA) [25]. The requirement for iron was based on $12 \%$ bioavailability and that for zinc on medium bioavailability [24]. For calcium the Acceptable Intake (AI) was defined as follows: $0 \%$ for calcium intakes $\leq$ one fourth of the AI, $25 \%$ for calcium intakes $>$ one fourth AI and $\leq$ one half AI, $50 \%$ for calcium intakes $>$ one half $\mathrm{AI}$ and $\leq$ three fourths $\mathrm{AI}, 75 \%$ for calcium intakes $>$ three fourths $\mathrm{AI}$ and $\leq \mathrm{AI}$, and $100 \%$ for 
Table 1. Characteristics of the subjects classified according to gender.

\begin{tabular}{|c|c|c|c|}
\hline Parameter & Females & Males & All subjects \\
\hline Number & 365 & 116 & 481 \\
\hline Age, years & $20.9 \pm 0.32$ & $16.3 \pm 0.42$ & $19.8 \pm 0.28$ \\
\hline$\leq 18$ y, $\%$ total, age, years & $38.5(15.5 \pm 0.18)$ & $65.5(13.7 \pm 0.33)$ & $45(14.8 \pm 0.17)$ \\
\hline$>18 \mathrm{y}, \%$ total & $61.5(24.3 \pm 0.36)$ & $35.5(21.7 \pm 0.47)$ & $55(23.9 \pm 0.32)$ \\
\hline Body weight, kg & $79.9 \pm 1.3$ & $77.9 \pm 2.9$ & $79.4 \pm 1.2$ \\
\hline Body height, cm & $159.3 \pm 0.44$ & $162.4 \pm 1.6$ & $160 \pm 0.52$ \\
\hline Waist circumference, $\mathrm{cm}$ & $89.4 \pm 1.0$ & $90.3 \pm 1.9$ & $89.6 \pm 0.86$ \\
\hline Hip circumference, cm & $110.7 \pm 1.0^{\mathrm{b}}$ & $103.3 \pm 1.67^{\mathrm{a}}$ & $109 \pm 0.84$ \\
\hline Waist/hip ratio & $0.81 \pm 0.006^{\mathrm{a}}$ & $0.87 \pm 0.009^{\mathrm{b}}$ & $0.82 \pm 0.005$ \\
\hline Waist/height ratio & $0.56 \pm 0.006^{\mathrm{b}}$ & $0.5 \pm 0.01^{\mathrm{a}}$ & $0.56 \pm 0.005$ \\
\hline BMI, $\mathbf{k g} \cdot \mathbf{m}^{2}$ & $31 \pm 0.44$ & $28.3 \pm 0.83$ & $30.3 \pm 0.39$ \\
\hline Leans ${ }^{*}, \%$ of total & 24 & 39.8 & 27.4 \\
\hline OW $^{*}+$ Obese $\%$ of total & 76 & 60.2 & 72.2 \\
\hline Dietary energy, kcal/day & $1502 \pm 31^{\mathrm{a}}$ & $1731.8 \pm 60.3^{\mathrm{b}}$ & $1561 \pm 28.1$ \\
\hline Protein, g/d & $59.2 \pm 1.47$ & $66.0 \pm 3.1$ & $61 \pm 1.35$ \\
\hline Carbohydrate, g/d & $223 \pm 5.1$ & $262.0 \pm 10.4$ & $233 \pm 4.68$ \\
\hline Total dietary fiber, g/day & $16.7 \pm 0.49^{\mathrm{a}}$ & $19.8 \pm 1.0^{\mathrm{b}}$ & $17.4 \pm 0.45$ \\
\hline Sugars, g/d & $24.9 \pm 0.94$ & $23.0 \pm 1.69$ & $24.4 \pm 0.82$ \\
\hline Fat, g/d & $47.5 \pm 1.12$ & $53.6 \pm 2.1$ & $49.1 \pm 1.0$ \\
\hline Saturated fatty acids, g/day & $22.7 \pm 0.84$ & $22.1 \pm 1.59$ & $22.5 \pm 0.75$ \\
\hline Nutrient density, kcal/g eaten & $1.6 \pm 0.02$ & $1.62 \pm 0.03$ & $1.61 \pm 0.02$ \\
\hline Protein, \% EI & $15.9 \pm 0.29$ & $15.3 \pm 0.45$ & $15.8 \pm 0.24$ \\
\hline CHO, \% EI & $59.2 \pm 0.6$ & $60.1 \pm 1.0$ & $59.3 \pm 0.52$ \\
\hline Fat, \% EI & $28.5 \pm 0.43$ & $28.3 \pm 0.69$ & $28.5 \pm 0.36$ \\
\hline SFA, \% EI & $13.8 \pm 0.46$ & $11.6 \pm 0.79$ & $13.3 \pm 0.4$ \\
\hline Food varieties, counts & $6.6 \pm 0.13$ & $6.6 \pm 0.23$ & $6.6 \pm 0.11$ \\
\hline HEI score & $45.8 \pm 0.74$ & $44.1 \pm 1.4$ & $45.5 \pm 0.66$ \\
\hline MPA, \% & $56.2 \pm 0.93$ & $58.3 \pm 1.54$ & $56.8 \pm 0.80$ \\
\hline NRF 9.3 score & $18.3 \pm 0.49$ & $17.8 \pm 0.55$ & $18.1 \pm 0.40$ \\
\hline NRF9 & $36.2 \pm 0.56^{\mathrm{b}}$ & $32.7 \pm 0.88^{\mathrm{a}}$ & $35.3 \pm 0.48$ \\
\hline LIM & $17.9 \pm 0.5^{\mathrm{b}}$ & $14.9 \pm 0.6^{\mathrm{a}}$ & $17.1 \pm 0.41$ \\
\hline
\end{tabular}

Mean standard error, ${ }^{*}$ Lean, BMI $=\leq 25 \mathrm{~kg} \cdot \mathrm{m}^{2}$; OW $=$ overweight $\mathrm{BMI}=>25 \mathrm{~kg} \cdot \mathrm{m}^{2}$.

calcium intakes above the AI. For example, the AI for calcium is $1000 \mathrm{mg} / \mathrm{d}$ for men and women 19 - $30 \mathrm{y}$ old; intakes between 0 and $250 \mathrm{mg} / \mathrm{d}$ would be given a $\% \%$ probability of adequacy, those between 251 and $500 \mathrm{mg} / \mathrm{d}$ would be given 25\%, those between 501 and $750 \mathrm{mg} / \mathrm{d}$ would be given 50\%, those between 751 and $1000 \mathrm{mg} / \mathrm{d}$ would be assigned $75 \%$, and those $>1000 \mathrm{mg} / \mathrm{d}$ would be assigned $100 \%$ [11]. The percentage of reference for 
each nutrient was capped at $100 \%$ daily value (DV) to avoid overvaluing by single nutrient for intakes above daily requirements.

The $\mathrm{NRF}_{9.3}$ score is based on the sum of the percentage of reference daily values (DVs) for nine beneficial nutrients: protein, dietary fiber, vitamin A, vitamin C, vitamin E, calcium, magnesium, iron and potassium minus the sum of the percentage of reference DVs for three nutrients to limit; saturated fat, total sugar ( mono- and disaccharides) and sodium. Firstly, all foods consumed by each subject were scored using the $\mathrm{NRF}_{9.3}$ algorithms followed by $\mathrm{NRF}_{9.3}$ score per 100 kcal [12] [15]. The Limited Nutrient (LIM) score included total sugars, sodium and saturated fatty acids in the score. And their appropriateness was evaluated.

Simple Pearson Spearman's correlations and regression algorithm were conducted using the food varieties, HEI, MPA or $\mathrm{NRF}_{9.3}$ as the dependent variable versus combinations of 16 nutrients of interest as independent variables [10].

\section{Results}

Table 1 presents the characteristics of all subjects and it shows that $27.4 \%$ of the subjects were lean with BMI $\leq$ $25 \mathrm{~kg} / \mathrm{m}^{2}$. Prevalences of subjects with a risk BMI over $25 \mathrm{~kg} / \mathrm{m}^{2}$ (overweight and obese) accounted for $72.6 \%$. The $24 \mathrm{~h}$ dietary recall data indicated that a total of 163 different food items were consumed by the participants with average daily intakes of (6) different food varieties within each of the primary foods/food groups (Table 1). The reported 163 foods were aggregated into 12 major foods/food groups (Table 2).

Figure 1 illustrates the shares of food groups on the basis of the intake over the $24 \mathrm{~h}$ dietary recall. Grains and grain products were dominating (43.1\%), whereas the shares of fruits $(2.8 \%)$ and dairy products $(10.5 \%)$ were quite poor.

The mean HEIs of the diets of the participants averaged $45.5 \%$, and there were no gender specific differences (Table 1). The nine subscores of the HEI were also examined in lean versus overweight/obese male and female subjects separately but no significant associations between HEI sub scores and an at-risk BMI were observed (data not shown). HEI scores were only weakly linked to anthropometric measures of health risk.

The mean total calorie intake by persons using data collected by the 24 hour recall were significantly higher $(P<0.05)$ among men $(1731.8 \pm 60.3 \mathrm{kcal})$ compared to respective women value $(1502 \pm 31 \mathrm{kcal} / \mathrm{day})$. Men generally had higher crude intakes for most of the individual nutrients compared to the respective women intakes (Table 1). When the macronutrient intakes were expressed as \% energy intake, there were similarities between men and women in the intakes of fat, protein, carbohydrates. The saturated fatty acids intake expressed

Table 2. Frequency of the consumption of 12 food groups/according distributed according to gender and age group.

\begin{tabular}{|c|c|c|c|c|c|c|c|}
\hline \multirow{2}{*}{ Index component } & \multirow{2}{*}{$\begin{array}{l}\text { Frequency } \\
\text { Total (481) }\end{array}$} & \multicolumn{3}{|c|}{ Frequency } & \multicolumn{3}{|c|}{ Frequency } \\
\hline & & $\begin{array}{l}\text { Females } \\
(n=365)\end{array}$ & $\begin{array}{c}\text { Males } \\
(n=116)\end{array}$ & Chi-square & $\begin{array}{c}\leq 18 \text { years } \\
(n=216)\end{array}$ & $\begin{array}{l}>18 \text { year } \\
(n=265)\end{array}$ & Chi-square \\
\hline Dairy products & 61.3 & 64.1 & 53.4 & $P<0.05$ & 55.1 & 66.4 & \\
\hline Eggs & 22.7 & 21.9 & 25.0 & & 20.8 & 24.2 & \\
\hline Extra foods & 49.3 & 51.0 & 44.0 & & 43.5 & 54.0 & \\
\hline Fishes & 12.3 & 9.9 & 19.8 & $P<0.005$ & 13.9 & 10.9 & \\
\hline Fruits & 22.7 & 24.4 & 19.0 & & 15.7 & 28.3 & \\
\hline Meats & 59.0 & 60.3 & 55.2 & & 54.2 & 63.0 & \\
\hline Other cereals & 78.2 & 76.7 & 82.8 & & 78.7 & 77.7 & \\
\hline Potato fried & 27.2 & 28.5 & 24.1 & & 29.2 & 25.7 & \\
\hline Soda & 11.2 & 13.2 & 6.9 & & 8.3 & 13.6 & \\
\hline Sugar & 6.4 & 7.1 & 4.3 & & 1.9 & 10.2 & \\
\hline Vegetables & 76.3 & 74.5 & 83.6 & $P<0.05$ & 75.0 & 77.4 & \\
\hline Whole grains & 74.6 & 74.2 & 78.4 & & 72.2 & 76.6 & \\
\hline
\end{tabular}




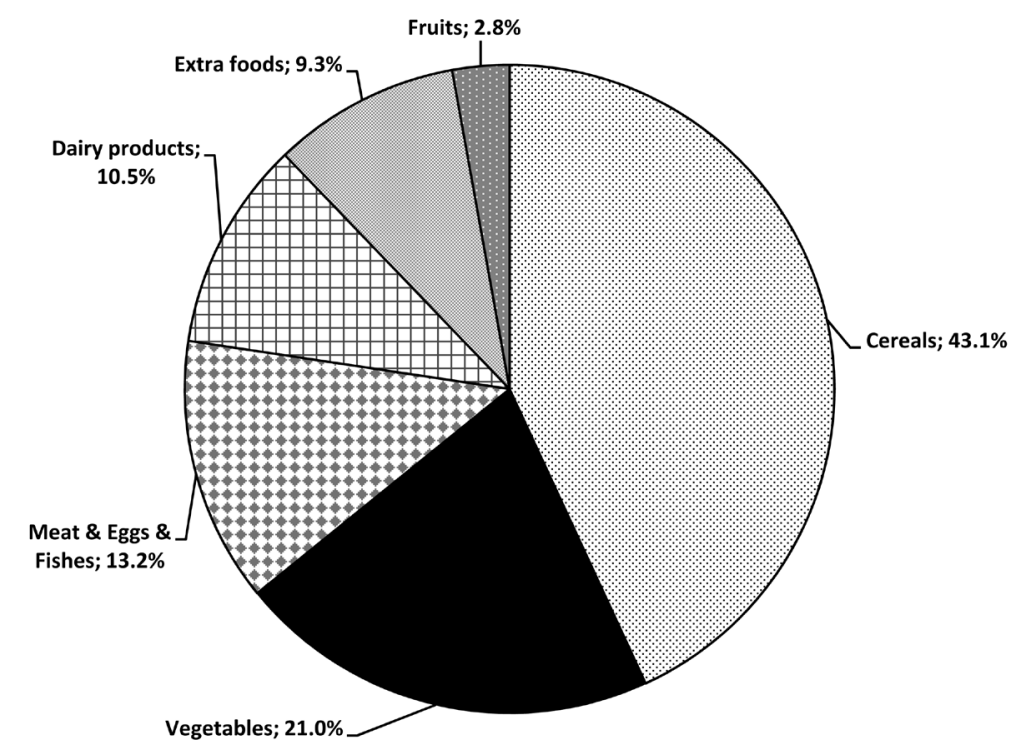

Figure 1. Nutrition circle illustrating the distribution (g \%) of the 6 top food groups to the daily diets of the participants.

as $\%$ EI was lower in the male diet $11.6 \% \pm 0.79 \% \mathrm{EI}$ ) than the respective figure of $13.8 \% \pm 0.46 \%$ in the female diet $(P<0.05)$.

Table 3 presents mean daily intakes of 12 food groups/foods distributed according to gender and age groups. Daily cereal intakes (whole grains and other cereals) averaged $555 \mathrm{~g}$ followed by soda and beverages with mean daily intake of $322.3 \pm 9.6$. The disaggregation approach was used for food categorization from population average consumption of each food group and the overall contributions of the top food sources to the daily supply of \% total calorie and essential nutrients of concern were calculated (Table 4). Bread and rice contributed more than $58 \%$ of calories, one third (33.6\%) of the protein, (32.9\%) of the fat, (64.2\%) of the fiber and (65.3\%) of vitamin B1. The meat group was the next top contributor of energy in the daily diet (12.2\%). Chicken were the most popular type of meat (63.8\%), followed by beef $(18.7 \%)$, processed meats $(10.7 \%)$ and liver $6.7 \%$. The meat group contributed also to the daily supply of total protein (33.7\%), vitamin A (47.9\%), vitamin B12 (83.6\%) and iron (18.3\%). All fruits contributed to one third (32\%) of the vitamin C supply; different potatoes contributed one fifth of the daily vitamin C; the rest was derived from different vegetables other than potatoes (68\%). Dairy products were the major contributor of calcium (46.2\%); the remaining 54\% of calcium was provided by grains, vegetables, meats and eggs. Cheeses were the most frequently consumed form of dairy products (38.6\%), whereby yoghurt was lowest (4.1\%). Milks were consumed as fluid milk or as drinks with other ingredients such as chocolate or fruits in the proportion of 17.3:40. Dairy products contributed also to $35.7 \%$ of the saturated fatty acids. Cheeses and meats were major sources of essential nutrients to the Egyptian diet contributing $4.0 \%$ and $48 \%$ of the vitamin A; 29.4 and 6.4 of the vitamin B2; $7 \%$ and $84 \%$ of the vitamin B12 and $46 \%$ and $10 \%$ of the calcium, respectively. Meanwhile, respective contribution of cheeses and meats to total saturated fatty acids (SFA) in the diet were $35.7 \%$ and $45.7 \%$. Extra foods were consumed by $49.3 \%$ of the total participants and contributed to calories by $36.7 \%$. High fat foods were defined as foods containing $>40 \%$ of total energy and consisted of bakeries such as cakes and gateau, chocolates, halawa (7\%) and salty potato chipsy (7.5\%). The chipsy contributed $20 \%$ of daily vitamin C and other plant fat rich snacks contributed to one fifth of the vitamin $\mathrm{E}$ and nothing more.

High-sugar drinks (jams, juices, sodas) were defined as products with $>25 \%$ of total energy as sugar accounted for $24.6 \%$ of the intakes. A comparison between milk drinkers and soda drinkers showed that the proportion of subjects with low calcium intake less than $500 \mathrm{mg}(246.5 \pm 12.4 \mathrm{mg})$ didn't differ from those with high calcium intake $(716.9 \pm 17.6 \mathrm{mg})$ in the average daily intake of sodas $36.1 \pm 5.5$ and $44.8 \pm 10.8 \mathrm{~g}$, respectively (Chi sqare test, $P>0.05$ ).

Nutrients intakes and probability of adequacy.

Mean probability of adequacy (MPA) averaged 56.3\% and were similar for men and women, except for low 
Table 3. Mean daily intakes of 12 food groups/foods distributed according to gender and age groups.

\begin{tabular}{|c|c|c|c|c|c|}
\hline \multirow{3}{*}{ Index component } & \multirow{3}{*}{$\begin{array}{l}\text { Daily intake (g/d) } \\
\text { All subjects } \\
(\mathbf{N}=\mathbf{4 8 1})\end{array}$} & \multirow{2}{*}{\multicolumn{2}{|c|}{$\begin{array}{c}\text { Daily intake (g/d) } \\
\text { Gender }\end{array}$}} & \multirow{2}{*}{\multicolumn{2}{|c|}{$\begin{array}{l}\text { Daily intake (g/d) } \\
\text { Age group (years) }\end{array}$}} \\
\hline & & & & & \\
\hline & & $\begin{array}{l}\text { Females } \\
(\mathrm{N}=365)\end{array}$ & $\begin{array}{c}\text { Males } \\
(\mathrm{N}=116)\end{array}$ & $\begin{array}{l}\leq 18 \text { years } \\
(N=216)\end{array}$ & $\begin{array}{l}>18 \text { year } \\
(N=265)\end{array}$ \\
\hline Dairy products & $169.0 \pm 3.79$ & $157.1 \pm 7.72$ & $171.4 \pm 4.33$ & $154.9 \pm 5.70^{\mathrm{a}}$ & $178.5 \pm 5.03^{b}$ \\
\hline Eggs & $67.8 \pm 5.40$ & $65.1 \pm 8.98$ & $68.8 \pm 6.63$ & $50.2 \pm 2.76^{\mathrm{a}}$ & $80.2 \pm 8.69^{b}$ \\
\hline Extra foods & $106.5 \pm 4.86$ & $128.7 \pm 11.15$ & $100.4 \pm 5.37$ & $93.5 \pm 6.96$ & $115.0 \pm 6.59$ \\
\hline Fishes & $170.3 \pm 4.91$ & $166.5 \pm 9.20$ & $172.8 \pm 5.55$ & $175.9 \pm 6.57$ & $164.6 \pm 7.38$ \\
\hline Fruits & $123.9 \pm 5.40$ & $145.8 \pm 10.30$ & $115.6 \pm 6.18$ & $128.1 \pm 8.48$ & $121.9 \pm 6.88$ \\
\hline Meats & $160.3 \pm 4.03$ & $170.5 \pm 8.47$ & $157.4 \pm 4.59$ & $165.0 \pm 6.23$ & $157.1 \pm 5.28$ \\
\hline Other cereals & $363.9 \pm 6.60$ & $395.8 \pm 12.52$ & $353.0 \pm 7.74$ & $388.9 \pm 9.64^{\mathrm{b}}$ & $343.3 \pm 9.05^{\mathrm{a}}$ \\
\hline Potato fried & $75.1 \pm 3.29$ & $87.0 \pm 9.57$ & $71.2 \pm 3.21$ & $73.2 \pm 5.40$ & $76.9 \pm 3.98$ \\
\hline Soda & $322.3 \pm 9.59$ & $363.8 \pm 33.75$ & $302.0 \pm 9.01$ & $325.6 \pm 16.33$ & $320.7 \pm 11.99$ \\
\hline Sugar & $57.6 \pm 12.63$ & $203.0 \pm 6.94^{\mathrm{a}}$ & $109.6 \pm 1.85^{\mathrm{b}}$ & $107.5 \pm 8.44^{\mathrm{b}}$ & $50.2 \pm 1.12^{\mathrm{a}}$ \\
\hline Vegetables & $246.2 \pm 3.83$ & $266.3 \pm 7.45^{\mathrm{a}}$ & $237.2 \pm 4.45^{\mathrm{b}}$ & $227.6 \pm 5.51^{\mathrm{a}}$ & $260.9 \pm 5.28^{\mathrm{b}}$ \\
\hline Whole grains & $191.1 \pm 3.21$ & $220.9 \pm 7.24^{\mathrm{a}}$ & $178.9 \pm 3.37^{\mathrm{b}}$ & $189.5 \pm 4.58$ & $192.3 \pm 4.46$ \\
\hline
\end{tabular}

Mean values are significantly different $(P<0.05)$, if they don't share the same alphabet within the same row (Student's-t test).

Table 4. Major top food group contributors to energy, macro- and micro nutrients in the diet of the subjects.

\begin{tabular}{|c|c|c|c|c|c|c|c|c|c|c|}
\hline \multirow[b]{2}{*}{ Index component } & \multicolumn{10}{|c|}{ Contribution \% } \\
\hline & Dairy & Eggs & Fishes & Meats & $\begin{array}{c}\text { All } \\
\text { cereals }\end{array}$ & Legumes & $\begin{array}{c}\text { Potatoes, } \\
\text { Cooked \& fried }\end{array}$ & $\begin{array}{c}\text { All } \\
\text { vegetables }\end{array}$ & Fruits & $\begin{array}{l}\text { Extra } \\
\text { foods* }\end{array}$ \\
\hline Energy & 7.20 & 1.63 & 2.10 & 12.20 & 58.27 & 4.90 & 1.34 & 8.34 & 0.95 & 5.37 \\
\hline Amount & 10.46 & 1.55 & 2.11 & 9.56 & 43.13 & 6.20 & 4.04 & 16.81 & 2.83 & 9.30 \\
\hline Protein & 9.73 & 2.40 & 6.26 & 33.66 & 33.60 & 5.23 & 1.01 & 7.73 & 0.48 & 1.39 \\
\hline Total Fat & 15.71 & 3.75 & 3.22 & 20.98 & 32.91 & 7.34 & 2.31 & 11.25 & 0.28 & 5.42 \\
\hline SFA & 35.70 & 1.08 & 2.90 & 45.70 & 8.90 & 0.19 & 0.54 & 1.54 & 0.04 & 3.85 \\
\hline PUFA & 4.24 & 3.49 & 7.01 & 31.46 & 22.55 & 1.14 & 5.67 & 10.95 & 0.25 & 19.10 \\
\hline Carbohydrates & 2.26 & 0.49 & 0.37 & 2.29 & 78.07 & 3.84 & 1.90 & 7.82 & 1.44 & 4.80 \\
\hline Starch & 0.07 & 0.29 & 0.00 & 0.01 & 94.33 & 2.52 & 0.00 & 2.68 & 0.00 & 0.10 \\
\hline Sugar & 14.46 & 0.45 & 0.35 & 0.78 & 30.57 & 1.82 & 1.06 & 11.68 & 9.70 & 30.70 \\
\hline Fiber & 0.13 & 0.00 & 0.00 & 0.00 & 64.16 & 15.84 & 0.84 & 16.46 & 1.90 & 1.74 \\
\hline Calcium & 46.16 & 6.60 & 1.70 & 9.80 & 14.40 & 4.60 & 0.10 & 13.95 & 1.54 & 1.30 \\
\hline Phosphorus & 19.42 & 1.97 & 4.53 & 13.37 & 44.70 & 6.16 & 1.70 & 8.66 & 0.26 & 1.49 \\
\hline Magnesium & 6.81 & 1.35 & 2.06 & 8.29 & 63.94 & 5.06 & 3.67 & 12.80 & 1.00 & 1.78 \\
\hline Potassium & 8.24 & 1.92 & 1.30 & 10.58 & 41.41 & 11.94 & 5.20 & 24.10 & 1.80 & 2.70 \\
\hline Sodium & 25.67 & 2.61 & 4.40 & 14.02 & 36.88 & 4.20 & 4.25 & 12.60 & 0.17 & 2.48 \\
\hline Iron & 2.10 & 0.33 & 1.19 & 18.30 & 64.97 & 5.79 & 0.51 & 6.67 & 0.26 & 0.41 \\
\hline Zinc & 9.46 & 1.91 & 0.81 & 25.98 & 38.73 & 12.16 & 2.48 & 9.40 & 0.51 & 1.46 \\
\hline Retinol equiv & 3.95 & 1.73 & 0.63 & 47.88 & 0.52 & 0.00 & 0.00 & 46.90 & 0.95 & 0.07 \\
\hline Vitamin E & 11.19 & 4.90 & 1.69 & 6.22 & 24.98 & 15.00 & 6.18 & 21.70 & 2.07 & 12.70 \\
\hline Thiamine & 2.87 & 2.27 & 1.29 & 7.66 & 65.28 & 3.07 & 7.27 & 20.10 & 0.87 & 1.36 \\
\hline Riboflavin & 29.40 & 0.73 & 0.00 & 6.38 & 59.97 & 0.38 & 0.00 & 2.80 & 0.00 & 0.31 \\
\hline Vitamin B6 & 7.82 & 3.27 & 4.57 & 23.71 & 39.55 & 0.00 & 6.67 & 17.06 & 1.68 & 2.47 \\
\hline Niacin & 8.83 & 1.19 & 4.10 & 34.01 & 33.17 & 8.60 & 0.00 & 9.20 & 0.00 & 0.86 \\
\hline Folate & 7.08 & 3.14 & 0.22 & 7.88 & 34.67 & 6.28 & 5.53 & 40.37 & 0.75 & 1.64 \\
\hline Vitamin B12 & 7.04 & 1.30 & 7.05 & 83.59 & 0.53 & 0.00 & 0.00 & 0.33 & 0.00 & 0.16 \\
\hline Vitamin C & 2.18 & 0.90 & 0.00 & 0.00 & 0.62 & 1.79 & 19.92 & 67.90 & 32.10 & 4.00 \\
\hline
\end{tabular}


probability of adequacy for iron among the females $(P<0.05)$ compared to the respective male PA (Table 5 and Figure 2). Age-specific significant differences were found in the MPA and in probability of adequacy (ANOVA) of zinc, vitamins A, C, B12, niacin and folate in favour of older youths with mean age of 23.9 years compared to lower mean values among youth aged 14.7 years.

The $\mathrm{NRF}_{9.3}$ index score were identical $(P>0.05)$ among males and females averaging $17.8 \pm 0.55$ and $18.3 \pm$ 0.49 , respectively (Table 1 ).

Table 6 presents the differences in food and nutrients intakes among quartiles of the $\mathrm{NRF}_{9.3}$ index score. Subjects in the highest quartile of the $\mathrm{NRF}_{9.3}$ index score $(28.2 \pm 0.45)$ were significantly $(P<0.05)$ older $(20.7$ \pm 0.5 years) compared to those in the lowest $\mathrm{NRF}_{9.3}$ quartile $(8.2 \pm 0.47)$ with the respective mean age (18.5 \pm 0.48 years). The BMI values were comparable in the four quartiles of the $\mathrm{NRF}_{9.3}$ index score. Subjects in the highest quartile of the $\mathrm{NRF}_{9.3}$ index score had a significantly lower total EI as compared to those in the lowest quartile. Subjects in the highest quartile of the $\mathrm{NRF}_{9.3}$ index score consumed significantly higher amounts of dietary fiber, vitamins and potassium $(P<0.05)$ as compared to those in the lowest quartile. However subjects in the highest quartile of the $\mathrm{NRF}_{9.3}$ index score consumed less carbohydrates, fat, protein, saturated fatty acids, sugars and sodium $(P<0.05)$ as compared to those in the lowest quartile.

Interestingly, the \% energy from carbohydrate in the highest quartile (60.3\%) was comparable to the respective energy from carbohydrate (59\%) in the lowest quartile; both figures are at the high-end of the Acceptable Macronutrient Distribution Range (AMDR) for carbohydrate intake. All food and nutrient indices, i.e., food varieties, HEI, MPA and $\mathrm{NRF}_{9.3}$ were significantly higher in the highest $\mathrm{NRF}_{9.3}$ quartile $(P<0.05)$ compared to those in the low $\mathrm{NRF}_{9.3}$ quartile (Table 6).

Table 5. Probability of adequacies (PA) and mean probability of adequacy (MPA) of the participants distributed according to gender and to age group.

\begin{tabular}{|c|c|c|c|c|c|c|c|c|c|c|c|c|}
\hline \multirow{2}{*}{ Nutrient } & \multicolumn{2}{|c|}{ All subjects } & \multicolumn{2}{|c|}{ All Females } & \multicolumn{2}{|c|}{ All males } & \multicolumn{2}{|c|}{ Subjects $\leq 18$ years } & \multicolumn{2}{|c|}{ Subjects $>18$ years } & \multirow{2}{*}{ 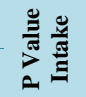 } & \multirow{2}{*}{ 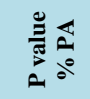 } \\
\hline & Intake/24 h & $\%$ PA & Intake/24 h & $\% \mathbf{P A}$ & Intake /24 h & $\% \mathbf{P A}$ & Intake/24 h & $\%$ PA & Intake/24 h & P\% PA & & \\
\hline 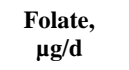 & $251.1 \pm 7.01$ & $57.9 \pm 1.28$ & $245.0 \pm 8.01$ & $56.3 \pm 1.48$ & $270.2 \pm 14.24$ & $62.8 \pm 2.44$ & $233.0 \pm 0.68$ & $54.7 \pm 0.13$ & $265.3 \pm 9.68$ & $60.3 \pm 1.74$ & $<0.01$ & $<0.01$ \\
\hline $\begin{array}{c}\text { Vitamin } \\
\text { B-12, } \\
\mu \mathrm{g} / \mathrm{d}\end{array}$ & $8.0 \pm 1.20$ & $56.0 \pm 1.60$ & $9.1 \pm 1.50$ & $55.5 \pm 1.84$ & $4.6 \pm 1.51$ & $57.7 \pm 3.16$ & $6.6 \pm 0.11$ & $51.8 \pm 0.17$ & $9.2 \pm 1.71$ & $59.2 \pm 2.05$ & $<0.005$ & $<0.05$ \\
\hline $\begin{array}{l}\text { Calcium, } \\
\text { mg/d }\end{array}$ & $364.8 \pm 11.40$ & $32.9 \pm 1.02$ & $368.2 \pm 13.41$ & $33.3 \pm 1.19$ & $354.1 \pm 21.12$ & $31.6 \pm 2.00$ & $347.8 \pm 1.21$ & $26.9 \pm 0.09$ & $378.2 \pm 14.74$ & $26.2 \pm 1.52$ & & $<0.0001$ \\
\hline $\begin{array}{c}\text { Riboflavin, } \\
\text { mg/d }\end{array}$ & $0.4 \pm 0.01$ & $32.6 \pm 1.15$ & $0.4 \pm 0.02$ & $33.1 \pm 1.34$ & $0.4 \pm 0.03$ & $30.9 \pm 2.22$ & $0.3 \pm 0.00$ & $31.4 \pm 0.13$ & $0.4 \pm 0.02$ & $34.2 \pm 1.55$ & & \\
\hline $\begin{array}{c}\text { Niacin, } \\
\text { mg/d }\end{array}$ & $15.3 \pm 0.58$ & $75.2 \pm 1.20$ & $15.3 \pm 0.71$ & $74.3 \pm 1.38$ & $15.1 \pm 0.86$ & $77.9 \pm 2.34$ & $14.6 \pm 0.05$ & $72.1 \pm 0.12$ & $15.8 \pm 0.82$ & $77.4 \pm 1.58$ & & $<0.05$ \\
\hline $\begin{array}{l}\text { Iron, } \\
\text { mg/d }\end{array}$ & $28.6 \pm 0.70$ & $86.1 \pm 1.08$ & $27.5 \pm 0.77$ & $83.3 \pm 1.28$ & $31.9 \pm 1.63$ & $95.2 \pm 1.61$ & $27.2 \pm 0.07$ & $84.6 \pm 0.11$ & $29.6 \pm 0.99$ & $87.3 \pm 1.42$ & & $<0.01$ \\
\hline $\begin{array}{c}\text { Thiamin, } \\
\text { mg/d }\end{array}$ & $1.1 \pm 0.02$ & $80.8 \pm 1.04$ & $1.1 \pm 0.03$ & $80.3 \pm 1.21$ & $1.2 \pm 0.06$ & $82.6 \pm 2.04$ & $1.1 \pm 0.00$ & $79.4 \pm 0.11$ & $1.1 \pm 0.04$ & $81.9 \pm 1.39$ & & \\
\hline $\begin{array}{c}\text { Vitamin } \\
\text { B-6, } \\
\text { mg/d }\end{array}$ & $0.7 \pm 0.01$ & $51.4 \pm 1.04$ & $0.6 \pm 0.02$ & $49.7 \pm 1.15$ & $0.7 \pm 0.03$ & $57.0 \pm 2.27$ & $0.6 \pm 0.00$ & $51.7 \pm 0.11$ & $0.7 \pm 0.02$ & $51.1 \pm 1.40$ & & $<0.05$ \\
\hline $\begin{array}{l}\text { Vitamin } \\
\text { C, mg/d }\end{array}$ & $15.1 \pm 0.97$ & $30.1 \pm 1.38$ & $15.2 \pm 1.10$ & $29.9 \pm 1.58$ & $14.9 \pm 1.84$ & $30.8 \pm 2.79$ & $12.1 \pm 0.08$ & $26.2 \pm 0.12$ & $18.0 \pm 1.42$ & $33.5 \pm 1.99$ & & $<0.01$ \\
\hline $\begin{array}{l}\text { Zinc, } \\
\text { mg/d }\end{array}$ & $8.7 \pm 0.21$ & $87.2 \pm 1.02$ & $8.5 \pm 0.23$ & $88.5 \pm 1.12$ & $9.4 \pm 0.43$ & $82.9 \pm 2.24$ & $8.2 \pm 0.02$ & $79.4 \pm 0.12$ & $9.0 \pm 0.29$ & $93.5 \pm 1.06$ & $<0.01$ & $<0.005$ \\
\hline MPA $^{*}$ & & $56.8 \pm 0.79$ & & $56.3 \pm 0.92$ & & $58.6 \pm 1.52$ & & $53.6 \pm 0.08$ & & $59.4 \pm 1.03^{*}$ & & $<0.001$ \\
\hline
\end{tabular}

Mean \pm standard error, ${ }^{*}$ The probability of adequacy for calcium was estimated using quartiles of the AI: 0\% for calcium intakes_one-fourth AI, 25\% for calcium intakes_one-fourth AI and_one-half AI, 50\% for calcium intakes_one-half AI and_three-fourths AI, 75\% for calcium intakes_hree-fourths AI and_AI, and $100 \%$ for calcium intakes above the AI. 
Table 6. Means (SE) of selected micronutrients across quartiles of the $\mathrm{NRF}_{9.3}$ index score.

\begin{tabular}{|c|c|c|c|c|c|}
\hline \multirow{3}{*}{ Index component } & \multicolumn{4}{|c|}{$\mathbf{N R F}_{9.3}$} & \multirow{3}{*}{$P$} \\
\hline & Q1 & Q2 & Q3 & Q4 & \\
\hline & Mean \pm SE & Mean \pm SE & Mean \pm SE & Mean \pm SE & \\
\hline Age & $18.5 \pm 0.48$ & $19.0 \pm 0.52$ & $20.0 \pm 0.56$ & $20.7 \pm 0.51$ & $<0.05$ \\
\hline Body weight, kg & $78.1 \pm 2.37$ & $81.8 \pm 2.44$ & $76.8 \pm 2.39$ & $80.8 \pm 2.43$ & \\
\hline BMI $\mathrm{kg} \cdot \mathrm{m}^{2}$ & $30.4 \pm 0.83$ & $30.8 \pm 0.78$ & $29.7 \pm 0.85$ & $30.4 \pm 0.69$ & \\
\hline Waist circumf, cm & $89.9 \pm 1.71$ & $92.1 \pm 1.63$ & $88.1 \pm 1.93$ & $88.1 \pm 1.61$ & \\
\hline Hip circumf, cm & $108.7 \pm 1.71$ & $111.0 \pm 1.48$ & $106.2 \pm 1.84$ & $109.6 \pm 1.71$ & \\
\hline Waist hip ratio & $0.8 \pm 0.01$ & $0.8 \pm 0.01$ & $0.8 \pm 0.01$ & $0.8 \pm 0.01$ & \\
\hline Waist height ratio & $56.8 \pm 1.12$ & $57.0 \pm 0.95$ & $55.1 \pm 1.19$ & $55.1 \pm 1.23$ & \\
\hline Food varieties & $5.7 \pm 0.23$ & $7.1 \pm 0.21$ & $7.0 \pm 0.20$ & $6.6 \pm 0.23$ & $<0.01$ \\
\hline HEI & $42.1 \pm 1.37$ & $47.3 \pm 1.36$ & $46.1 \pm 1.29$ & $46.3 \pm 1.20$ & $<0.05$ \\
\hline MPA & $44.3 \pm 1.68$ & $59.9 \pm 1.54$ & $62.3 \pm 1.18$ & $61.0 \pm 1.37$ & $<0.0001$ \\
\hline $\mathrm{NRF}_{9.3}$ & $8.2 \pm 0.71$ & $16.0 \pm 0.13$ & $20.3 \pm 0.11$ & $28.2 \pm 0.45$ & $<0.0001$ \\
\hline $\mathrm{NRF}_{9}$ & $28.1 \pm 0.75$ & $31.1 \pm 0.59$ & $35.9 \pm 0.45$ & $46.2 \pm 1.00$ & $<0.0001$ \\
\hline $\mathbf{L I M}_{3}$ & $20.0 \pm 1.13$ & $15.1 \pm 0.58$ & $15.5 \pm 0.44$ & $18.0 \pm 0.87$ & $<0.01$ \\
\hline Energy & $1523.6 \pm 67.67$ & $1812.7 \pm 60.37$ & $1637.7 \pm 40.33$ & $1274.9 \pm 38.48$ & $<0.0001$ \\
\hline Protein & $57.7 \pm 3.29$ & $69.8 \pm 2.69$ & $63.9 \pm 2.37$ & $52.8 \pm 2.08$ & $<0.005$ \\
\hline Fat & $49.9 \pm 2.18$ & $57.9 \pm 2.10$ & $50.9 \pm 1.69$ & $37.7 \pm 1.54$ & $<0.0001$ \\
\hline SFA & $25.7 \pm 1.82$ & $26.0 \pm 1.53$ & $23.5 \pm 1.20$ & $15.2 \pm 1.10$ & $<0.001$ \\
\hline Carbohydrates & $225.9 \pm 11.08$ & $267.8 \pm 10.66$ & $244.2 \pm 7.23$ & $193.6 \pm 6.74$ & $<0.01$ \\
\hline Dietary fiber, total & $12.9 \pm 0.91$ & $19.0 \pm 0.99$ & $19.4 \pm 0.82$ & $18.6 \pm 0.79$ & $<0.01$ \\
\hline Added sugar & $26.1 \pm 1.84$ & $26.4 \pm 1.77$ & $24.7 \pm 1.54$ & $20.2 \pm 1.37$ & $<0.05$ \\
\hline Retinol equivalent & $169.9 \pm 66.53$ & $890.9 \pm 160.99$ & $632.3 \pm 84.14$ & $1027.8 \pm 151.60$ & $<0.05$ \\
\hline Vit E & $2.0 \pm 0.17$ & $2.3 \pm 0.16$ & $2.7 \pm 0.20$ & $2.2 \pm 0.22$ & $<0.05$ \\
\hline Vitamin B1 & $0.9 \pm 0.05$ & $1.3 \pm 0.06$ & $1.2 \pm 0.04$ & $1.1 \pm 0.04$ & $<0.01$ \\
\hline Vitamin B2 & $0.3 \pm 0.03$ & $0.4 \pm 0.04$ & $0.4 \pm 0.03$ & $0.4 \pm 0.02$ & $<0.05$ \\
\hline Vitamin B6 & $0.6 \pm 0.03$ & $0.8 \pm 0.03$ & $0.7 \pm 0.02$ & $0.6 \pm 0.02$ & $<0.01$ \\
\hline Niacin & $11.8 \pm 0.84$ & $18.4 \pm 1.49$ & $15.1 \pm 0.72$ & $16.1 \pm 1.37$ & $<0.05$ \\
\hline Folic & $149.1 \pm 9.73$ & $280.5 \pm 16.51$ & $292.5 \pm 12.96$ & $282.8 \pm 12.40$ & $<0.0001$ \\
\hline Vitamin B12 & $3.3 \pm 1.27$ & $13.8 \pm 3.27$ & $3.6 \pm 1.23$ & $11.8 \pm 3.02$ & $<0.01$ \\
\hline Vitamin C & $7.0 \pm 0.94$ & $12.4 \pm 1.24$ & $15.1 \pm 1.79$ & $26.1 \pm 2.73$ & $<0.01$ \\
\hline Calcium & $292.3 \pm 18.87$ & $415.4 \pm 25.32$ & $429.5 \pm 24.50$ & $324.9 \pm 20.51$ & $<0.01$ \\
\hline Magnesium & $226.8 \pm 13.69$ & $300.9 \pm 13.33$ & $288.2 \pm 7.73$ & $252.0 \pm 8.10$ & $<0.01$ \\
\hline Iron & $24.5 \pm 1.73$ & $32.3 \pm 1.61$ & $30.7 \pm 1.17$ & $27.0 \pm 1.01$ & $<0.05$ \\
\hline Potassium & $1491.7 \pm 84.50$ & $2158.1 \pm 98.07$ & $2199.0 \pm 68.26$ & $1944.2 \pm 79.92$ & $<0.001$ \\
\hline Sodium & $2226.8 \pm 125.11$ & $2618.3 \pm 122.05$ & $2631.1 \pm 113.16$ & $2070.6 \pm 108.23$ & $<0.01$ \\
\hline
\end{tabular}



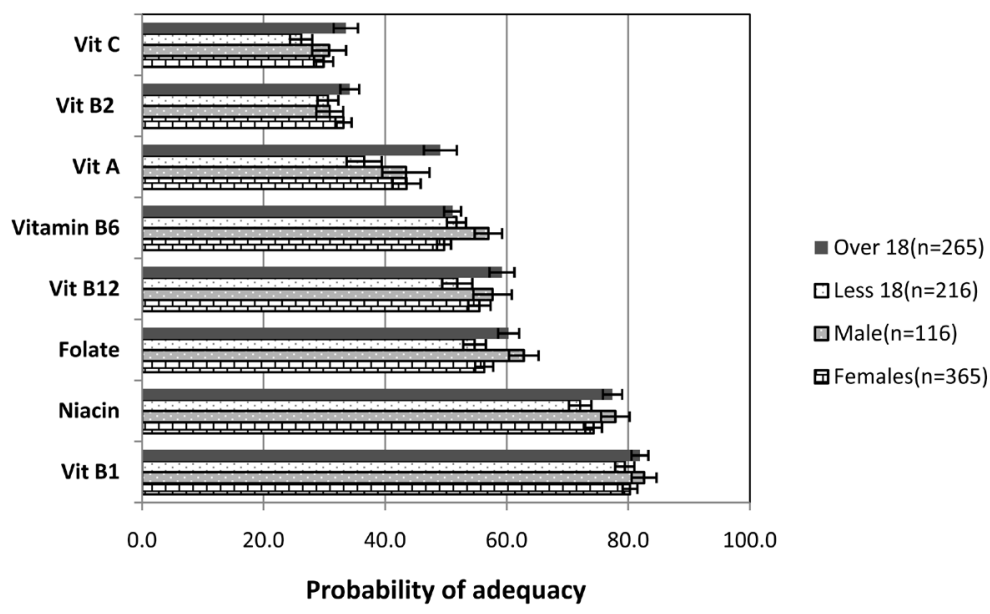

(a)

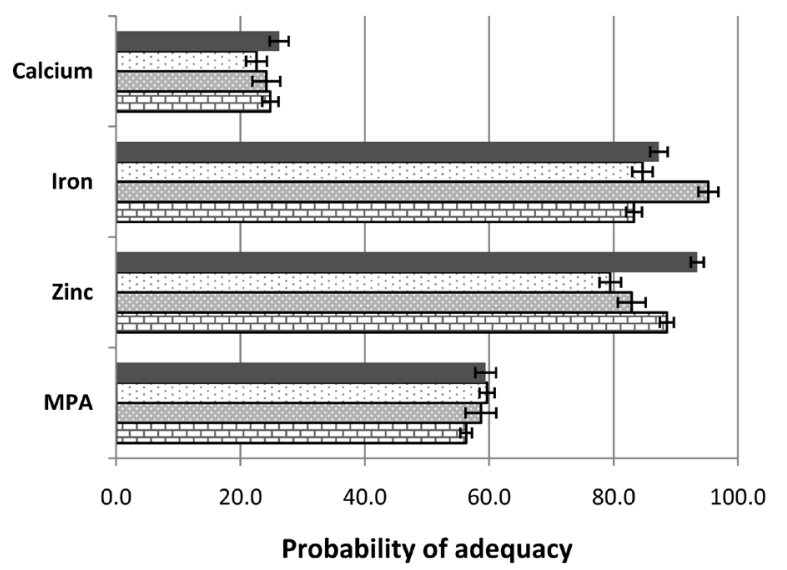

- Over $18(\mathrm{n}=265)$

$\square$ Less $18(\mathrm{n}=216)$

口Male $(\mathrm{n}=116)$

由Females $(n=365)$

(b)

Figure 2. (a) Probability of adequacy (PA) of eight vitamins; (b) PA of three minerals and mean Probability of adequacy (MPA) classified according to age group and gender.

Table 7 presents the simple Pearson Spearman correlation coefficients between the four indices: food varieties, HEI, MPA, $\mathrm{NRF}_{9.3}$ and indicator components of the diet and anthropometric measures of health risks. Linear regression analysis, showed inverse association of $\mathrm{NRF}_{9.3}$ index score with total EI $(\beta$ coefficient: -24.7 , $P$-value: $<0.0001)$. Only $\mathrm{NRF}_{9.3}$ index correlated negatively with the waist circumference and waist circumference height ratio, both are anthropometric measures of health risk. Figure 3 is a scatter diagram for the relation between $\mathrm{NRF}_{9.3}$ and the waist circumference height ratio with the regression line for best fitness.

\section{Discussion}

Recent publications are increasing the focus upon food diversification to ensure satisfying the basic population needs of micronutrient and the access to healthy foods [3]. The overall mean healthy eating index (HEI) with an average of 45 was suboptimal and indicative of a poor quality diet. Only $5.4 \%$ of the population had an HEI score of more than 70. The HEI-2010 scoring system reflects variation in nine out of ten vegetarian and omnivore versions of the foods pattern that constitute the index when based on 24-hour recalls [9]. Koshari is a popular dish consisting of gold lentils and rice. According to HEI, it is disaggregated into two food groups: grains and proteins. High HEI scores of $\geq 80$ were associated with healthier lifestyles; HEI scores of 51 - 80 indicated "needing improvement", and scores of less than 51 were considered "poor" [13]. HEI-2010 sodium scoring standard is energy-adjusted. The standard sodium level set at $1.1 \mathrm{~g} / 1000$ calories was reported to be more difficult to meet at lower energy levels compared to the absolute limit $7 \mathrm{~g}$ salt for men and $6 \mathrm{~g}$ for women [5]. 


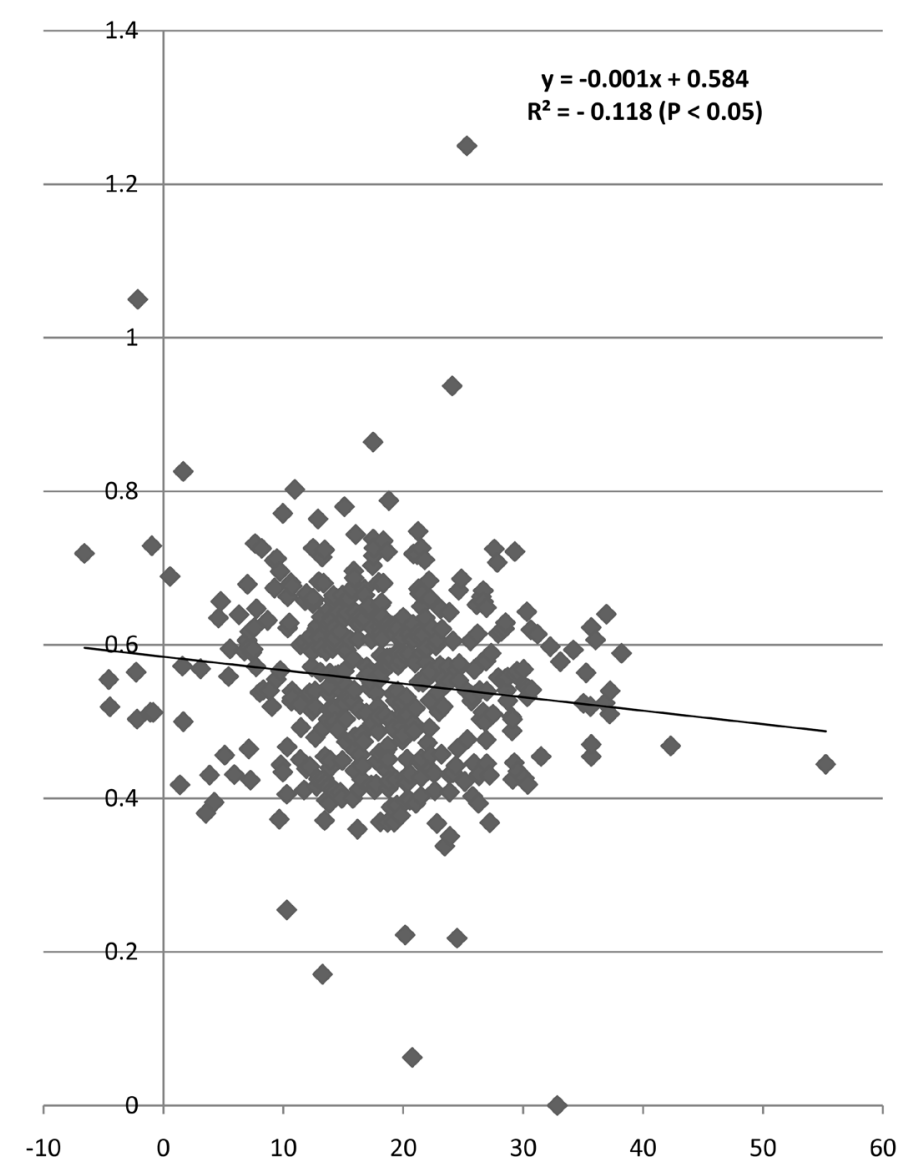

Figure 3. Scatter diagram for the relation between $\mathrm{NRF}_{9.3}$ and the waist circumference height ratio with the regression line for best fitness.

Table 7. Pearson correlation coefficients between food varieties, HEI, MPA and $\mathrm{NRF}_{9.3}$ and (10) independent variables.

\begin{tabular}{|c|c|c|c|c|}
\hline \multirow{2}{*}{ Index component } & \multicolumn{4}{|c|}{ Correlation } \\
\hline & MPA & $\mathbf{N R F}_{9.3}$ & HEI & Food varieties \\
\hline Age & & $0.103^{*}$ & $0.142^{* *}$ & $0.196^{* * *}$ \\
\hline BMI & -0.016 & $-0.088^{*}$ & -0.032 & -0.028 \\
\hline waist & -0.019 & $-0.106^{*}$ & -0.023 & 0.019 \\
\hline hip & -0.032 & -0.028 & -0.035 & -0.003 \\
\hline waist/hip & 0.035 & -0.037 & 0.019 & 0.019 \\
\hline waist/ht & -0.053 & $-0.119^{*}$ & -0.062 & $-0.090^{*}$ \\
\hline HEI & 0.358 & $0.161^{* *}$ & 1.000 & $0.699^{* * * *}$ \\
\hline MPA & 1.000 & $0.429^{* * *}$ & $0.358^{* * * *}$ & $0.652^{* * *}$ \\
\hline $\mathbf{N R F}_{9.3}$ & $0.429^{* * *}$ & 1.000 & $0.161^{* *}$ & $0.179^{* * * *}$ \\
\hline $\mathrm{NRF}_{9}$ & -0.057 & $0.578^{* * *}$ & 0.004 & $-0.175^{* *}$ \\
\hline $\mathbf{L I M}_{3}$ & -0.057 & $-0.288^{* * *}$ & $-0.151^{* *}$ & $-0.364^{* * *}$ \\
\hline Energy & $0.705^{* * *}$ & $-0.119^{*}$ & $0.273^{* * *}$ & $0.643^{* * *}$ \\
\hline SFA & $0.423^{* * *}$ & $-0.143^{* *}$ & $0.208^{* * * *}$ & $0.380^{* *}$ \\
\hline Dietary fiber, total & $0.582^{* * * *}$ & $0.230^{* * *}$ & $0.219^{* * * *}$ & $0.515^{* * *}$ \\
\hline Total sugar & $0.257^{* * *}$ & $-0.109^{*}$ & $0.449^{* * *}$ & $0.543^{* * * *}$ \\
\hline
\end{tabular}

${ }^{*}=P<0.05 ;{ }^{* *}=P<0.01,{ }^{* * *}=P<0.005,{ }^{* * * *}=P<0.001,{ }^{\wedge}=$ trend towards significance $(P<0.1)$. 
Nutrition surveys carried out in Nigeria [26] emphasized that at least five of ten food groups should be consumed daily, and based on the count of food varieties anaemic girls could be identified and differentiated from the non-anemic girls.

Optimum weight shares of grains, milk \& dairy products, eggs \& fishes \& meats, fruits, vegetables and oils of $30,18,7,17,26$ and 2, respectively had been recommended by the German nutrition society [3]. In the diet of our subjects, the respective proportions were 43.1, 10.5, 13.2, 2.5, 21 (oil not shown) reflects poor shares of the fruit and the dairy groups (Figure 1). No one food category contributes more than $7.2 \%$ of calories to the overall US diet. All grains contributed only $19 \%$ to the total calories and foods categorized as desserts, snacks or beverages, contributed $13.6 \%$ of total calories [27]. The present result shows that on the average 58.3\% of energy came from cereals and reflects a high reliance on few foods and consequently insufficient micronutrient intake. We assume that the subjects in the present study were being eating the same foods that other members of the family were eating, because the food consumption patterns observed in this study are consistent with patterns observed among the entire Egyptian population [28] [29]. Our result differs from an earlier study carried out on Egyptian obese girls aging 15 years, with respect to the intakes of dietary carbohydrates, fats, proteins and calcium [30].

A study reported an inverse association between the intakes of fat and saturated fatty acid with increasing intakes of dietary fiber (DF) and a high $\mathrm{NRF}_{9.3}$ index score had a lower EI than those subjects with a low index score [31]. Our results are in good agreement with the findings of those authors that $\mathrm{NRF}_{9.3}$ in the highest quartile had lowest report (Table 6). The same study reported that the nutrient-rich foods $\left(\mathrm{NRF}_{9.3}\right.$ and $\mathrm{NRF}_{9}$ ) were positively associated with BMI, body weight, waist circumference and waist-to-height ratio [31]. In the present study, the nutrient-rich foods $\left(\mathrm{NRF}_{9.3}\right)$ were negatively associated with waist circumference and waist-to-height ratio (Table 7, Figure 3). High positive significant correlation coefficient was found between $\mathrm{NRF}_{9.3}$ and estimated fiber intake $(r=0.23, P<0.001)$. The energy content of fiber per unit weight of food is low and accordingly, the inclusion of fiber in a diet effectively lowers the energy density and this is especially true for soluble fibers because they bind water. The DF has been recently identified as carbohydrate (CHO) polymers and oligomers materials (non-starch polysaccharides (NSP)) that escape digestion in the small intestine and pass into the large intestine, where they are slightly or nearly completely fermented [32]. DFs per se and their fermentation products contribute to many physiological benefits associated with their consumption. DF can directly influence the colon and microbiome, and its fermentation products can be absorbed from the large bowel to exert systemic influence in various parts of the body. High-fiber foods also increase gastric distension increasing the sensation of fullness and higher fiber content slows glucose absorption [33].

The analysis of 30 publications supports an induction of positive energy balance and weight gain in adults following the short-term feeding intake of sugar-sweetened sodas [34]. Consumption of sweetened syrup (sucrose and fructose) beverages (SSB) including the full spectrum of soft drinks, carbonated soft drinks, fruit drinks, sports drinks, energy drinks promotes accumulation of visceral adiposity, increased hepatic de novo lipogenesis and is the largest contributor to the long-term weight gain and obesity epidemic [34]. Evidence suggests that carbohydrates in liquid form may not have the same effect on satiety as that provided by food intake which over the long-term would theoretically result in excess energy intake and resulting weight gain. The percent of energy from carbohydrates and high-sugar drinks had inverse relationship with an at-risk BMI among Inuit adults in the Canadian high-arctic [13]. The present analysis reveals also that three categories ("soft drinks, soda," "candy, sugars and sugary foods") contributed $5 \%$ of total calorie intake and $30.7 \%$ of daily sugar intake. These extra foods provided $19 \%$ of the estimated poly unsaturated fatty acids, $12.7 \%$ of the estimated vitamin E and no other nutritional value.

Subjects with a high $\mathrm{NRF}_{9.3}$ index score were reported to have higher BMI, body weight, waist circumference and waist-to-height ratio [31]. Waist circumference was used as exclusive criteria in defining metabolically healthy obesity [35]. The $\mathrm{NRF}_{9.3}$ index score correlated weakly but significantly and inversely with waist circumference and waist circumference height ratio; this suggests that diets with high $\mathrm{NRF}_{9.3}$ are healthy food and protect against abdominal obesity, which is an independent risk factor for a number of co-morbidities and chronic illnesses, as well as a cluster of metabolic disturbances [15] [16].

\section{Limitations}

The present analyses examined only a single day of intake data. Although $1 \mathrm{~d}$ of intake is not representative of usual intake due to day-to-day variations [36], the $24 \mathrm{~h}$ dietary recall is still acceptable for population level study, which was conducted to cover the 4 seasons of the year. Preliminary examinations indicated that the findings would not have changed with the inclusion of $2 \mathrm{~d}$ of intake data, and thus it is likely that the associations seen 
for 1 day are similar to those that would be observed over a longer period of time.

Another limitation is that the calculated EI:BMR ratios for assessment of level of underreporting in this study were suboptimal, with greater underreporting among those with an at-risk BMI. The majority of the subjects in the present study were consuming two meals, late breakfast around noon and late dinner. Breakfast consumption has declined during the past 25 years in all age groups, especially among female adolescents. Omission of breakfast or consumption of an inadequate breakfast may contribute to dietary inadequacies, which are rarely replenished by other meals during the day [37].

The present finding confirms earlier Egyptian reports, which showed that eating behavior among college women was associated with increases in their body mass indices [38]. Finally, another limitation is that men were under-represented in the survey which may have resulted in biased estimates of population characteristics of men. Important strengths of the study are the use of standardized, validated instrument to measure and linear regression models were conducted to predict the best fit with anthropometric measures.

\section{Conclusion}

Youths, particularly those from low income may select fats and sweets because they provide dietary energy at the lowest possible cost [39], leading to deficit in the dietary intake of micronutrients and antioxidants and to health inequalities. Therefore, public heath challenges imply that effective means of nutrition intervention program policy [40] and dietary guidance directed to youths should receive more attention to include nutrient-dense, age-appropriate good alternative snacks such as dairy products and fruits.

\section{References}

[1] Inman, D.D., van Bakergem, K.M., LaRosa, A.C. and Garr, D.R. (2011) Evidence-Based Health Promotion Programs for Schools and Communities. American Journal of Preventive Medicine, 40, 207-219. http://dx.doi.org/10.1016/j.amepre.2010.10.031

[2] Verger, E.O., Mariotti, F., Holmes, B.A., Paineau, D. and Huneau, J.-F. (2012) Evaluation of a Diet Quality Index Based on the Probability of Adequate Nutrient Intake (PANDiet) Using National French and US Dietary Surveys. PLoS ONE, 7, e42155. http://dx.doi.org/10.1371/journal.pone.0042155

[3] Drescher, L.S., Thiele, S. and Mensink, G.B.M. (2007) A New Index to Measure Healthy Food Diversity Better Reflects a Healthy Diet Than Traditional Measures. Journal of Nutrition, 137, 647-651.

[4] Van Lee, L., Anouk, G., Eveline, J., Huysduynen, J., Pieter, V. and Edith, J. (2012) The Dutch Healthy Diet Index (DHD-Index): An Instrument to Measure Adherence to the Dutch Guidelines for a Healthy Diet. Journal of Nutritional Science, 2, e40. http://dx.doi.org/10.1017/jns.2013.28

[5] Drake, I., Gullberg, B., Ericson, U., Sonestedt, E., Nilsson, J., Wallstrom, P., Hedblad, B. and Wirfält, E. (2011) Development of a Diet Quality Index Assessing Adherence to the Swedish Nutrition Recommendations and Dietary Guidelines in the Malmo Diet and Cancer Cohort. Public Health Nutrition, 14, 835-845. http://dx.doi.org/10.1017/S1368980010003848

[6] Wong, J.E., Parnell, W.R., Howe, A.S., Black, K.E. and Skidmore, P.M.L. (2013) Development and Validation of a Food-Based Diet Quality Index for New Zealand Adolescents. BMC Pubic Health, 13, 562. http://dx.doi.org/10.1186/1471-2458-13-562

[7] Drewnowski, A. (2009) Defining Nutrient Density: Development and Validation of the Nutrient Rich Foods Index. Journal of the American College of Nutrition, 28, 421S-426S. http://dx.doi.org/10.1080/07315724.2009.10718106

[8] Fulgoni, V.L., Keast, D.R. and Drewnowski, A. (2009) Development and Validation of the Nutrient-Rich Foods Index: A Tool to Measure Nutritional Quality of Foods. Journal of Nutrition, 139, 1549-1554. http://dx.doi.org/10.3945/jn.108.101360

[9] Kennedy, G., Fanou-Fogny, N., Seghieri, C., Arimond, M., Koreissi, Y., Dossa, R., Kok, F.J. and Brouwer, I.D. (2010) Food Groups Associated with a Composite Measure of Probability of Adequate Intake of 11 Micronutrients in the Diets of Women in Urban Mali. Journal of Nutrition, 140, 2070S-2078S. http://dx.doi.org/10.3945/jn.110.123612

[10] Arsenault, J.E., Fulgoni, V.L., Hersey, J.C. and Muth, M.K. (2012) A Novel Approach to Selecting and Weighting Nutrients for Nutrient Profiling of Foods and Diets. Journal of the Academy of Nutrition and Dietetics, 112, 1968-1975. http://dx.doi.org/10.1016/j.jand.2012.08.032

[11] FAO/WHO (2003) Joint Expert Consultation. Diet, Nutrition and the Prevention of Chronic Diseases. A Joint FAO/WHO Consultation Meeting, WHO, Geneva.

[12] Foote, J.A., Murphy, S.P., Wilkens, L.R., Basiotis, P.P. and Carlson, A. (2004) Dietary Variety Increases the Probabil- 
ity of Nutrient Adequacy among Adults. Journal of Nutrition, 134, 1779-1785.

[13] Zienczuk, N., Young, T.K., Cao, Z.R. and Egeland, G.M. (2012) Dietary Correlates of an At-Risk BMI among Inuit Adults in the Canadian High Arctic: Cross-Sectional International Polar Year Inuit Health Survey, 2007-2008. Nutrition Journal, 11, 73. http://dx.doi.org/10.1186/1475-2891-11-73

[14] Vartanian, L., Schwartz, M. and Brownell, K. (2007) Effects of Soft Drink Consumption on Nutrition and Health: A Systematic Review and Meta Analysis. American Journal of Public Health, 97, 667-75. http://dx.doi.org/10.2105/AJPH.2005.083782

[15] Rangan, A.M., Schindeler, S., Hector, D.J., Gill, T.P. and Webb, K.L. (2009) Consumption of "Extra” Foods by Australian Adults: Types, Quantities and Contribution to Energy and Nutrient Intakes. European Journal of Clinical Nutrition, 63, 865-871. http://dx.doi.org/10.1038/ejcn.2008.51

[16] Ferreira, I., Twisk, J.W.R., van Mechelen, W., Kemper, H.C.G. and Stehouwer, C.D.A. (2005) Development of Fatness, Fitness, and Lifestyle from Adolescence to the Age of 36 Years Determinants of the Metabolic Syndrome in Young Adults: The Amsterdam Growth and Health Longitudinal Study. Archives of Internal Medicine, 165, 42-48. http://dx.doi.org/10.1001/archinte.165.1.42

[17] Casanueva, F.F., Moreno, B., Rodríguez-Azeredo, R., Massien, C., Conthe, P., Formiguera, X., Barrios, V. and Balkau, B. (2010) Relationship of Abdominal Obesity with Cardiovascular Disease, Diabetes and Hyperlipidaemia in Spain. Clinical Endocrinology, 73, 35-40.

[18] Janssen, V., Peter, T. and Robert, R. (2004) Waist Circumference and Not Body Mass Index Explains Obesity-Related Health Risk. The American Journal of Clinical Nutrition, 79, 379-384.

[19] (2014) Egypt Demographic and Health Survey. 1-52.

[20] Zaki, M.E., Ezzat, W., Elhosary, Y.A. and Saleh, O.M. (2013) Factors Associated with Nonalcoholic Fatty Liver Disease in Obese Adolescents. Macedonian Journal of Medical Sciences, 6, 273-277.

[21] (2000) The Precise Egyptian Food Composition Table (unpublished data).

[22] McCance and Widdowson’s Composition of Foods Integrated Dataset (CoFID) (2015) Food Data Ranks. 1-13.

[23] WHO (2003) Fruit and Vegetable Promotion Initiative. Report of the Meeting, 25-27 August 2003, World Health Organization, Geneva.

[24] FAO-WHO (2004) Vitamin and Mineral Requirements in Human Nutrition. 2nd Edition, WHO, Geneva.

[25] Schroeder, S., Alexandra, F., Christina, V., Mike, B., Constance, S., Myriam, D. and Olaf, H. (2008) Nutrition Concepts for Elite Distance Runners Based on Macronutrient and Energy Expenditure. Journal of Athletic Training, 43, 489-504.

[26] Olumakaiye, M.F. (2013) Adolescent Girls with Low Dietary Diversity Score Are Predisposed to Iron Deficiency in Southwestern Nigeria. Infant, Child, \& Adolescent Nutrition, 5, 85-91. http://dx.doi.org/10.1177/1941406413475661

[27] Hu, F. and Malik, V. (2010) Sugar-Sweetened Beverages and Risk of Obesity and Type 2 Diabetes: Epidemiologic Evidence. Physiology \& Behavior, 100, 47-54. http://dx.doi.org/10.1177/1941406413475661

[28] Hussein, L., Hermann-Kunz, E., Dortschy, E., Kojlmeier, L. and Kuhn, G. (1995) Food Consumption Patterns and Nutrient Intakes among Selected Egyptian Employees Differing in Their Socioeducational Status. Egyptian Journal of Nutrition, 10, 75-112.

[29] Padilla, M., Ahmed, Z.S. and Wassef, H.H. (2005) In the Mediterranean Region: Overall Food Security in Quantitative Terms but Qualitative Insecurity. CIHEAM Analytic Note, No. 4, June 2005, 1-100.

[30] Youssef, M.M., Mohsen, M.A., Abou El-Soud, N.H. and Kazem, Y.A. (2010) Energy Intake, Diet Composition among Low Social Class Overweight and Obese Egyptian Adolescents. The Journal of American Science, 6, 160-168.

[31] Streppel, M.T., de Groot, L.C. and Feskens, E.J. (2012) Nutrient-Rich Foods in Relation to Various Measures of Anthropometry Family Practice, 29, i36-i43. http://dx.doi.org/10.1093/fampra/cmr093

[32] Jones, J.M. (2014) CODEX-Aligned Dietary Fiber Definitions Help to Bridge the “Fiber Gap”. Nutrition Journal, 13, 34. http://dx.doi.org/10.1186/1475-2891-13-34

[33] Burton-Freeman, B. (2000) Dietary Fiber and Energy Regulation. The American Journal of Clinical Nutrition, 130, 2725-2755.

[34] Malik, V.S., Pan, A., Willett, W.C. and Hu, F.B. (2013) Sugar-Sweetened Beverages and Weight Gain in Children and Adults: A Systematic Review and Meta-Analysis. The American Journal of Clinical Nutrition, 98, 1084-1102. http://dx.doi.org/10.3945/ajcn.113.058362

[35] Stefan, N., Häring, H.-U., Hu, F.B. and Schulze, M.B. (2014) Metabolically Healthy Obesity: Epidemiology, Mechanisms, and Clinical Implications. The Lancet, 1, 152-162. www.thelancet.com/diabetes-endocrinology

[36] Willett, W.C., Sacks, F., Trichopoulou, A., Drescher, G., Ferro-Luzzi, A., Helsing, E. and Trichopoulos, D. (1995) 
Mediterranean Diet Pyramid: A Cultural Model for Healthy Eating. The American Journal of Clinical Nutrition, 61, 1402S-1406S.

[37] Nicklas, T.A., O’Neil, C. and Myers, L. (2004) The Importance of Breakfast Consumption to Nutrition of Children, Adolescents, and Young Adults. Nutrition Today, 39, 30-39.

[38] Saleh, Z., Abdel Razek, F. and Hussein, L. (2002) Composition of Energy Intake and Eating Behaviors among College Women Differing in Their Body Mass Indices. Egyptian Journal of Nutrition, 17, 85-107.

[39] Andrieu, E., Darmon, N. and Drewnowski, A. (2006) Low-Cost Diets: More Energy, Fewer Nutrients. European Journal of Clinical Nutrition, 60, 434-436. http://dx.doi.org/10.1038/sj.ejcn.1602331

[40] Buttriss, J.L., Briend, A., Darmon, N., Ferguson, E.L., Maillot, M. and Lluch, A. (2014) Diet Modeling: How It Can Inform the Development of Dietary Recommendations and Public Health Policy. Nutrition Bulletin, 39, 115-125. http://dx.doi.org/10.1111/nbu.12076 